latched on to the popularity of energy as a topic for endless talk and took "Energy and equity" as the theme. Australia is going through an excitable phase over energy matters. Australia's huge coal reserves are proving immensely attractive to foreign interests. Oil shale deposits, notably in Queensland, were the subject of wildly optimistic predictions of national self-sufficiency in oil, until the dominant Exxon partners pulled back on grounds of massively increased cost estimates.

Unfortunately, the symposia which offered well-known people a chance to air their well-known views did not significantly advance the professional, popular or political understanding of the facts and issues. Full publication of these addresses is unlikely, and the brief mentions they received in newspapers caused little impact. The organizers failed to capitalize on the large media contingent present with the energy theme buried in a snowstorm of unrelated items. The paper which attracted most news reporting and comment - even a newspaper leader - was a sociological study of the sub-culture of nudist colonies.

ANZAAS congresses suffer from a lack of continuity. Each meeting is organized in a different city by a totally different group. ANZAAS also seems to have no collective memory, so that the failings of one meeting are repeated. Its central organization is weak because it depends too much on volunteers - its membership subscription income remains static and it receives no government subsidy.

The enrolment of 2,300 at the Brisbane congress was disappointing, being right on the financial break-even point. ANZAAS will therefore now have to struggle financially for another year in the hope that next year's meeting in Sydney will attract enough delegates to lift its spirits and wipe out its deficit.

For all its faults, however, ANZAAS remains a potent force in Australian (not New Zealand) academic life, which could realise its potential if only it could get its act together. This year's congress came only two weeks after Prime Minister Malcolm Fraser announced a series of cost-cutting measures recommended by a group of senior ministers, popularly known as the "'Razor Gang". The Razor Gang slashed into the supposed "fat" of publicly funded science and did so to an extent probably greater than any other single area. An undiscriminating cut of $2-3$ per cent in the staffing levels of all public service operations will hit CSIRO hard, though this has as yet not been publicly recognized. Another act of the Razor Gang - the imposition of fees for second degrees in universities - is the cause of nationwide protests by staff and students alike.

Fears for the future health of Australian science were all the talk at ANZAAS, but only privately. Not a murmur was heard publicly about these problems. ANZAAS 1981 may well be remembered as an opportunity lost.

\section{Mitterand's new ministers On your Marx}

With the all-important French legislative elections looming on 14 and 21 June which will determine whether the new socialist president, François Mitterand, has real power or not - it may be unwise to read too much into the events of the past few days. But Mitterand's much-vaunted commitment to science seems in fact to be one to technology - albeit technology with a socialist mask.

Mitterand has appointed Jean-Pierre Chevènement, a 42-year-old left-wing intellectual and founder of the Centre for Socialist Studies, Research and Education (the broadly Marxist CERES), as Minister of State for Research and Technology. The other principal contender for the job, the scientist and director of the Institut Pasteur, Professor François Gros, has been appointed as scientific advisor to the Prime Minister, M. Pierre Mauroy.

Chevènement is a great admirer of the highly-centralized Japanese ministry for industry and technology, MITI; and as a Minister of State he will be a member of Mitterand's powerful inner cabinet of five. He will rank higher even than the Minister of Industry, M. Pierre Joxe (who, incidentally, also calls himself a Marxist).

Chevènement and Joxe are now locked in battle over who will control which of France's many scientific and technological institutions. The Delegation Générale pour la Recherche Scientifique et Technique (DGRST), which draws up guidelines and coordinates research throughout the government, but has only a small autonomous budget will be Chevènement's of right; and it seems he has also won control of the principal body funding basic science in France, the Centre National de la Recherche Scientifique (CNRS), from the ministry of education. The Centre National pour les Etudes Spatiales (CNES) which controls France's scientific and technological work in space, may also be a major prize from the ministry of industry, and another could be the Agence Nationale de Valorisation de la Recherche (ANVARD), which promotes innovation in French industry. The control of the medical research body (INSERM) and the agricultural research council (INRA) is also in question.

Even the atomic energy authority (the CEA) might fall to Chevenement, but once the dust of Mitterand's energy policy has settled, the science and technology minister will be seen to be strongly pro-nuclear (see box). He is also greatly interested in nuclear weapons (he backs a French strategic nuclear capability), and in military research.

Where is socialism - let alone Marxism - in all this? It comes partly in nationalization: Mitterand has promised to nationalize nine big industrial companies, to give greater state control of major technical sectors of the French economy (this will be M. Joxe's preoccupation). It comes in promised efforts towards less centralized, more democratic control of technological decision making (Mitterand speaks of a referendum on nuclear power, for example). And it may come in Chevènement's professed concern for the impact of new technologies on employment and working conditions. His attitude to the problem of short-term contracts for young researchers and technicians, which has flared up regularly in the universities, CNRS, INSERM and INRA in recent years is not yet clear.

Robert Walgate

\section{French face energy questions}

Energy policy in France is entering a rather confused period. The new government has cancelled the bitterly contested plans for a nuclear power station at Plogoff in Brittany but has announced the start-up of two new 900 MW stations at Gravelines and Tricastin. And when the outgoing government in its dying days gave the go-ahead for doubling the size of the spent fuel reprocessing plant at Cap de la Hague there was no demur from the already-elected Mitterand.

So where lies the new French government's energy policy? There is no energy minister in the new government. The President, it seems, would like to keep this difficult card in French politics to himself. And so far, in fact, Mitterand's pre-election promises and his first actions as President have been consistent. He offered only a "pause" to reconsider nuclear power, in which reactors under construction (like Tricastin and Gravelines) would continue to completion; Plogoff has not begun. And Cap de la Hague has been so inefficient it needs refurbishment to cope with future spent fuel.

But there is disagreement in his cabinet about what to do next. Some say Plogoff is cancelled; others, that it is merely postponed. Mitterand may call some kind of referendum (and if he does, is likely to find the French in favour of nuclear power) or he may opt for a parliamentary inquiry, through his promised committee on technology assessment, or he may hold a public inquiry.

But barring accidents like Three Mile Island, France's nuclear programme will probably survive the storms, because the country needs the energy, and soon. Despite the vociferous opposition at Plogoff last year, the electorate of the region in fact voted overwhelmingly for pro-nuclear candidates in the first round of the recent presidential elections. The (Giscardian) member of parliament for the region complained last week "where will it be possible at sure cost, to find 5,200 MW for Brittany by 1990 ? And another 4,200 jobs?". Robert Walgate 